\title{
Biogas Production from Co-Digestion of Grass with Food Waste
}

\author{
Hamidatu S. Darimani' ${ }^{1}$, Dinesh C. Pant ${ }^{2}$ \\ ${ }^{1}$ Department of Agricultural Engineering, School of Engineering, Wa Polytechnic, Wa, Upper West, Ghana \\ ${ }^{2}$ The Energy and Resources Institute (TERI), Darbari Seth Block, Habitat Centre, New Delhi, India \\ Email: hamidatu.darimani@wapoly.edu.gh,hamidnid2012@gmail.com,dpant@teri.res.in
}

How to cite this paper: Darimani, H.S and Pant, D.C. (2020) Biogas Production from Co-Digestion of Grass with Food Waste. Journal of Agricultural Chemistry and Environment, 9, 27-36.

https://doi.org/10.4236/jacen.2020.91003

Received: January 17, 2020

Accepted: February 22, 2020

Published: February 25, 2020

Copyright (c) 2020 by author(s) and Scientific Research Publishing Inc. This work is licensed under the Creative Commons Attribution International License (CC BY 4.0).

http://creativecommons.org/licenses/by/4.0/ (c) (i) Open Access

\begin{abstract}
Management of grasslands in Ghana has become so poor that most rural communities result in bushfires that cause a lot of environmental challenges. Grass could be used for biogas generation. This study investigated the effect of grass and food waste co-digestion on the biogas yield and clarified how the addition of grass enhances the AD performance. Grass (GR) mixed with the co-substrate food waste (FW) was then evaluated under anaerobic conditions for the production of biogas (methane). Five laboratory-scale reactors, R1 (100\% FW, 0\% GR), R2 (75\% FW, 25\% GR), R3 (50\% FW, 50\% GR), R4 (25\% FW, 75\% GR) and R5 ( $0 \%$ FW, 100\% GR) were set up with different proportions of grass and food waste which had $8 \%$ total solid concentration. Digestion was carried out for twenty (20) days at room temperature, $35^{\circ} \mathrm{C} \pm 2^{\circ} \mathrm{C}$. The biogas yield in the R1, R2, R3, R4, R5 was 805, 840, 485, 243 and $418 \mathrm{~mL}$ respectively. Food waste only produced $805 \mathrm{~mL}$ and grass only produced 418 $\mathrm{mL}$ of biogas. Food waste only produced $50 \%$ more biogas than grass. However, co-digestion at $75 \% \mathrm{FW}, 25 \%$ resulted in $6 \%$ more biogas than food waste only.
\end{abstract}

\section{Keywords}

Grass, Co-Substrate, Food Waste, Anaerobic Digestion, Biogas

\section{Introduction}

Grasslands play an important role in global agriculture covering around 26\% of world's total land area [1]. In most developing countries, grasses are the main plant species in verges along roads, dams and on river dikes, for that reason, the hectares of grassland available are difficult to quantify. Besides its role as basic nutrient for herbivores and ruminants, grassland has a key role in the prevention 
of erosion, the immobilization of leaching minerals and carbon storage, helps in the regularization of water regimes and in the purification of pesticides and fertilizers. It also serves to furnish a habitat for wildlife, both flora and fauna and contributes to the attractiveness of the landscape [2] [3] [4].

In recent years, considerations on grassland use for bioenergy have increased considerably, mainly for biogas production and as solid fuel for combustion [5]. As well as for biogas production, grasses can be used in future for the production of lignocellulosic bioethanol, synthetic natural gas or synthetic biofuels. Previous studies have shown that grass represents a category of surplus lignocellulosic biomass, and it can also be used for biogas production [6]. The main benefits of using grass for bioenergy production are its lower water consumption for growth than other crops and the fact that it can be cultivated in non-arable lands, without competing with food crops [7] [8] [9].

At present, food waste (FW) regarded as municipal waste is sent to landfills and incineration plants as final disposal points. In some ways, these processes release some stress from garbage siege; at the same time, a series of problems are emerging including the rising cost of waste disposal, the lack of land space, groundwater pollution by leachate, and the emission of toxic and greenhouse gases [10]. Sometimes animals are fed with these wastes. FW is a desirable material to co-digest with grass because of its high biodegradability [11].

Anaerobic Digestion (AD) is a biochemical technology for the treatment of organic wastes and the production of biogas, which can be used as a fuel for heating or co-generation of electricity and heat. Anaerobic digestion of grass has been extensively researched and demonstrated. Previous studies [1] [6] have demonstrated that grass is a desirable material for biogas production. However, based on investment returns from energy production, the economics of grass are not favourable due to the relatively low biodegradability especially when no pre-treatment is done [1]. Biogas yield of grass, as compared to many other types of organic wastes such as food waste has been low. One of the approaches for improving the economics of grass is to increase their biogas production rate by co-digesting the grass with more degradable wastes.

Co-digestion of different materials may enhance the anaerobic digestion process due to better carbon and nutrient balance [12] [13] [14]. According to Mata-Alvarez et al. [14] [15], digestion of more than one substrate in the same digester can establish positive synergism and the added nutrients can support microbial growth. During mesophilic anaerobic co-digestion of cattle manure and fruit and vegetable wastes (FVW) in a continuous stirred tank reactor (CSTR) at $35^{\circ} \mathrm{C}$, Callaghan et al. [16] (2002) found that increasing the percentage of FVW from $20 \%$ to $50 \%$ increased the methane yield from 230 to $450 \mathrm{~L} / \mathrm{kg}$ VS added. Misi and Forster [17] found that batch co-digestion, at $35^{\circ} \mathrm{C}$, of cattle manure with molasses (50\% on dry weight basis) increased the biogas yield from 60 to $230 \mathrm{~L} / \mathrm{kg}$ VS added.

The above discussions highlight that biogas is considered to be an important component of the future renewable energy mix. Given its nature it has great 
flexibility to be converted to electricity, stored as a pressured gas or cleaned and used in a gas grid or as transport fuel. Many options exist for its production and of these grassland show significant promise. This study was initiated to investigate the feasibility of adding food waste into grass to enhance the biogas production. The work is also aimed to add knowledge to the anaerobic digestion of grass and food waste degradation. This study aims to: 1) Investigate the effect of grass and food waste co-digestion on the biogas yield; 2) clarify how the addition of grass enhances the $\mathrm{AD}$ performance.

\section{Materials and Methods}

\subsection{Inoculum and Substrates}

Microbial inoculum (sludge) was collected from a mesophilic operating anaerobic bioreactor from the bio-methanation plant at TERI GRAM, India. Food waste and grass were the substrates used. Mechanical pre-treatment (Chipping) was carried out to reduce the size of grass for better digestion [18] [19]. After chipping the final particle size of grass was usually between 10 - $30 \mathrm{~mm}$ [19]. Grass was collected in a polythene bag and transferred to the laboratory. The pre-treatment used for the food waste was grinding [20]-[24]. Substrate ratio for food waste and grass was varied to maintain the $\mathrm{C} / \mathrm{N}$ ratio. No chemical treatment was carried out on the materials before use.

\subsection{Experimental Design}

Batch experiments were carried out in the laboratory. The digestion test was carried out using $300 \mathrm{~mL}$ glass bottles with a working volume of $225 \mathrm{~mL}$. The experiment was operated at $37^{\circ} \mathrm{C} \pm 2^{\circ} \mathrm{C}$ for twenty (20) days. The experimental conditions are given in Table 1 . The experimental conditions were carried out to examine the influence of co-digestion ratio (R1 to R5) on biogas yield. The concentrations of the substrate were based on organic loading mass [25]. The amount of volatile solids (VS) of the inoculum and the substrate were calculated based on the predetermined co-digestion ratio. For all experiments, fresh water

Table 1. Experimental conditions of the batch tests.

\begin{tabular}{cccccc}
\hline \multicolumn{5}{c}{ Experimental Design } \\
\hline & $\begin{array}{c}\text { Co-digestion Ratio, Food } \\
\text { waste (FW): Grass (GR) (\%) }\end{array}$ & $\begin{array}{c}\text { Quantity, } \\
\text { FW: GR (g) }\end{array}$ & Pre-treatment \\
\hline & FW & GR & FW & GR & \\
\hline Experiment & 100 & 0 & 75.00 & 0.00 & Grinding \\
R1 & 75 & 25 & 56.25 & 18.75 & \\
R2 & 50 & 50 & 37.50 & 37.50 & \\
R3 & 25 & 75 & 18.75 & 56.25 & \\
R4 & 0 & 100 & 0.00 & 75.00 & Chipping \\
R5 & & & & &
\end{tabular}


was added, and no additional nutrients/trace elements were added to the reactors as it was assumed that they are provided by the inoculum (anaerobic sludge).

Studing the reactors (R1, R2, R3, R4, and R5), the influence of the different co-digestion of food waste and grass on biogas production, food waste was used as the sole substrate and inoculum was added for R1, while grass was the sole substrate in R5 and the inoculum was added. The experimental conditions of the batch test were chosen based on trail preliminary experiments in the laboratory. The designed percentages (see experimental set-ups) of waste were put in the digester and water was added at a ratio of 1:2. This was placed in a BOD incubator for six (6) days without the addition of culture. This acidification stage was carried out for 6 days. The $\mathrm{pH}$ was adjusted with Sodium Hydroxide $(\mathrm{NaOH})$. The methanogenic culture was added after the sixth day. Biogas production started the next day and the monitoring of the gas was done for twenty (20) days. The daily gas production was recorded as Daily Gas Yields (DGY) by measurement of displaced water every morning. This is done by noting the quantity of water displaced by the gas collected in the measuring cylinder.

\subsection{Analytical Techniques}

\subsubsection{Organic Carbon}

Organic carbon was determined by the method of Datta et al. (1962) [26]. A known quantity $(1.0 \mathrm{~g})$ of completely dried and powdered waste was taken in a $250 \mathrm{ml}$ conical flask, then $10 \mathrm{ml}$ of $1 \mathrm{~N}$ potassium dichromate $\left(\mathrm{K}_{2} \mathrm{Cr}_{2} \mathrm{O}_{7}\right)$ was added and mixed thoroughly. After mixing, $20 \mathrm{ml}$ of the concentrated sulphuric acid $\left(\mathrm{H}_{2} \mathrm{SO}_{4}\right)$ was added and kept for 4 - 5 hours. The mixture was diluted by adding $100 \mathrm{ml}$ distilled water and kept for 1 hour for waste particles to settle. The optical density of clear solution was measured at $645 \mathrm{~nm}$. The organic carbon was calculated using sucrose as standard.

\subsubsection{Total Nitrogen}

Total nitrogen was estimated by the method of Jackson (1967) [27]. One gram of waste was heated with $5 \mathrm{ml}$ concentrated sulphric acid slowly until the solution was clear. The contents were made up to $50 \mathrm{ml} .5 \mathrm{ml}$ aliquote of the solution was transferred to Kjeldahl distillation apparatus and heated. The distillate was collected in $5 \mathrm{ml}$ of $4 \%$ boric acid and then titrated with standard $0.01 \mathrm{NHCl}$. The nitrogen content was calculated using the titre value.

\subsubsection{COD Estimation}

Total and soluble COD of the waste slurry was monitored during the course of the digestion to check the digestion level of the slurry. A homogenised paste of the waste was used for total COD determination. For soluble COD estimation, slurry was centrifuged at $8000 \mathrm{rpm}$ for 20 minutes and then supernatant was analysed for COD according to standard methods (APHA) [28].

\subsubsection{Total Solids, Volatile Solids and Fixed Solids Estimation}

For TS, a known amount of sample was transferred into a previously weighed 
crucible and dried at $110^{\circ} \mathrm{C}$ for 24 hours. For volatile solids (VS) estimation, dried sample obtained after TS estimation was ignited in a muffle furnace at $550^{\circ} \mathrm{C}$ for 4 hours and for fixed solids, the residue left in the vessel after a sample is ignited (heated to dryness at $550^{\circ} \mathrm{C}$ ) was estimated [28].

\section{Results and Discussions}

\subsection{Chemical Composition of Raw Substrate}

Table 2 shows the composition of raw substrate used in the digestion process. It is clear from the table that grass has a low $\mathrm{pH}$ which can be attributed to the high concentration of volatile fatty acids (VFAs) in the waste of above $800 \mathrm{mg} / \mathrm{l}$ which was also reported by Abu-Dahrieh J. K. et al. [29]. The increased VFA content could be as a result of the fermentation of the grass. The VFAs in the waste are then used directly in the acetogenesis stage to produce acetic acid, which is then used by the methanogens to produce methane.

\subsection{Daily Biogas Production Rate}

All the experiments were carried out under daily mean temperature range of $37^{\circ} \mathrm{C} \pm 2^{\circ} \mathrm{C}$ throughout the period of biogas production. The results of the experiment carried out for the twenty (20) days indicated that blending of field grass with the food waste affected the total biogas yield and onset of gas flammability for each of the biogas systems. Biogas production from all the rectors commenced within 24 hours after the acidification process of six (6) days. During the acidification process, $\mathrm{pH}$ dropped to 5 on the third day and it was reset to 7. This could be due to the fact that Volatile Fatty Acid (VFA) is possibly high. If the VFAs are not utilized at the rate they are produced, then it can kill the methanogenic activity due to lower $\mathrm{pH}$. Feng et al. [30] reported that the possible acidogenic biological pathways that lead to a varied distribution of the VFAs, mainly is a function of $\mathrm{pH}$. Maximum biogas was produced on the first day in all rectors. Daily biogas production from the grass and food waste is graphically shown in Figure 1.

Table 2. Characterization of raw materials used in the biogas digester.

\begin{tabular}{cccc}
\hline S/N & Parameters & Food Waste (FW) \% & Grass (GR) \% \\
\hline 1 & Moisture (\%) & 74.79 & 62.32 \\
2 & TS (\%) & 25.21 & 38.1 \\
3 & VS (\%) & 92.87 & 77.04 \\
4 & Fixed Solids (\%) & 7.13 & 22.96 \\
5 & Organic Carbon (\%) & 82.35 & 71.20 \\
6 & Nitrogen, N (\%) & 2.15 & 1.98 \\
7 & C:N Ratio & $38: 1$ & $35: 1$ \\
8 & pH & 3.80 & 3.40 \\
9. & COD (mL/g of $\left.\mathrm{O}_{2}\right)$ & $18,557.82$ & $13,768.71$ \\
\hline
\end{tabular}




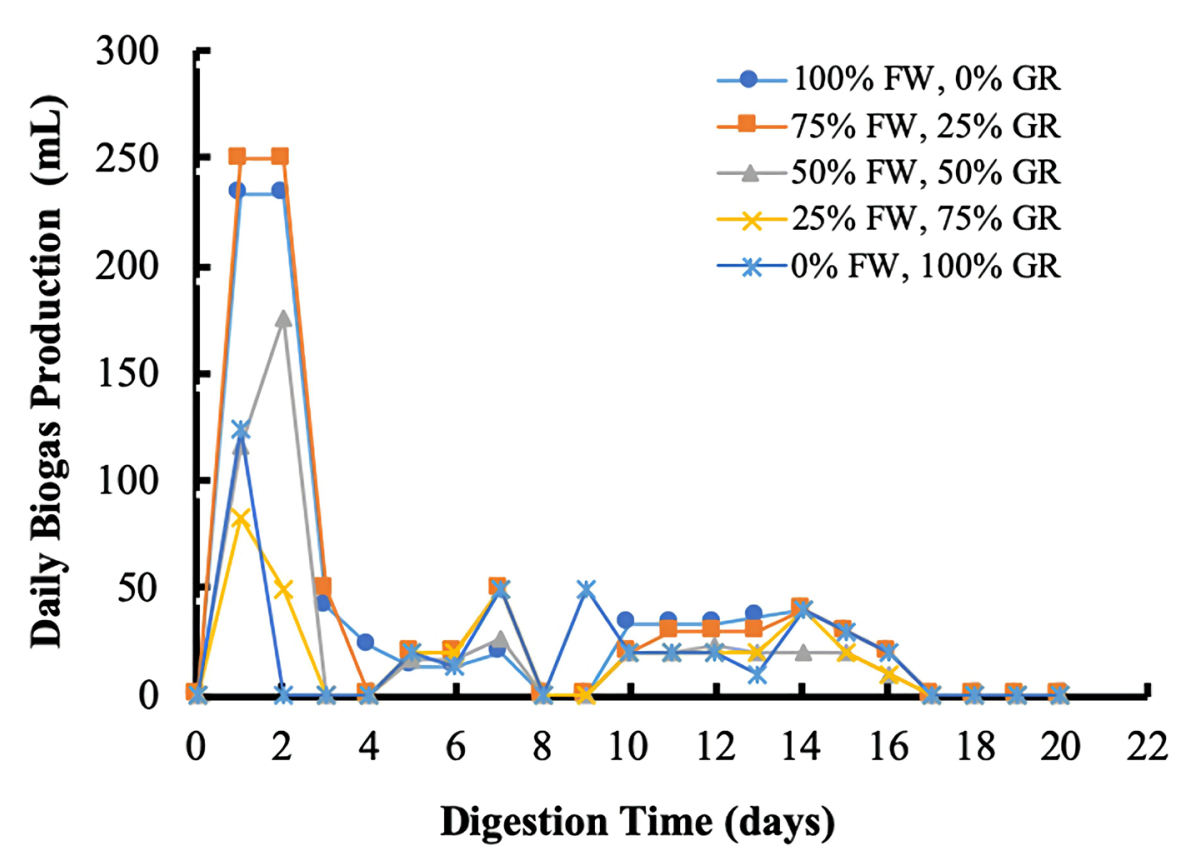

Figure 1. Daily biogas production of co-digestion of food waste and grass in different percentages.

It is observed in Figure 1 that the reactor 1 (R1) i.e. 100\% FW produced the highest daily biogas yield of $233 \mathrm{~mL}$. Grass only (R5) produced the lowest daily biogas yield of $125 \mathrm{~mL}$. Food waste produced 50\% more than grass only (R5). This is probably due to the lignocellulose structure of grass. Cellulose and hemicellulose are polysaccharides that can be hydrolyzed into simple sugars. Lignin which acts as a support to the cell structure, embedding cellulose and hemicellulose, hinders the susceptibility to microbial attack during hydrolysis process [31]. The main aim of the pretreatment is to break the lignin layer that protects the cellulose and hemicellulose, in order to make the biomass more accessible for digestion [31]. Co-digestion at 75\% FW and 25\% GR (R2) resulted in 6\% more than food waste only. Figure 1 illustrates daily biogas production for all reactors over a period of twenty (20) days. For all of the reactors, there is a sharp increase in the amount of biogas produced during the first 1 - 2 days of the experiment. This is then followed by a sharp decrease following the near-complete consumption of the different substrates in the reactors. This was due to the increased availability of the biomass during the initial stages, leading to subsequent growth of the anaerobic organisms. After 3 days the rate of biogas production began to decrease due to a reduction in nutrient content. The samples show that there was a decrease in $\mathrm{pH}$ from $\mathrm{pH} 7.0$ - 5.0 over the course of the experiment for all reactors. The dropped $\mathrm{pH}$ was reset to 7 .

At the beginning of gas production, the anaerobes present in the organic material became active and began increasing in population [31]. When gas production began to rise, they were fully established and were acting on more substrate. At the peak of production, they were acting on the maximum amount of organic 
matter possible. After this point, gas production began to drop because the excess substrates were being converted to methane. At this point also, there is a steady decline in the amount of substrate available to the bacteria to act on [31]. There is also a decrease in either carbon or nitrogen available for use. When one becomes exhausted, the process slows gradually to a stop. This decline continues until gas production gradually comes to an end. While the process progresses, the condition becomes more appropriate for the methane forming bacteria. This led to an increase in the percentage composition of methane in the biogas produced until the maximum level is reached. Thus as fermentation approaches the end, the burning characteristics of the biogas improve [32].

\subsection{Results of Different Experiments (Ratios) for Optimum Production}

Figure 2 shows the commutative biogas yield for the experimental setup R1 to R5. Cumulative Biogas Yield for R4 made up of $25 \%$ food waste and $75 \%$ grass recorded $243 \mathrm{~mL}$. This may be due to the high cellulose content of the grass. The small amount of anaerobic bacteria present will take more time to establish itself and begin biogas production. The sample made of $50 \%$ grass and $50 \%$ food waste (R3), and those made up of $25 \%$ grass and $75 \%$ food waste (R2), $100 \%$ food waste (R1) and 100\% grass (R5) recorded 485, 840, 805 and $418 \mathrm{~mL}$ of biogas yield respectively.

Co-digestion of $25 \%$ grass and $75 \%$ food waste (R2) produced the maximum biogas. This is similar to the study of Okonkwo et al. [33]. They reported that a maximum volume of biogas, $809 \mathrm{~cm}^{3}$ was produced by the sample containing $50 \%$ poultry dropping and $50 \%$ weeds. This indicates that this sample possesses the best $\mathrm{C} / \mathrm{N}$ ratio of all the samples prepared. Different materials have their $\mathrm{C} / \mathrm{N}$

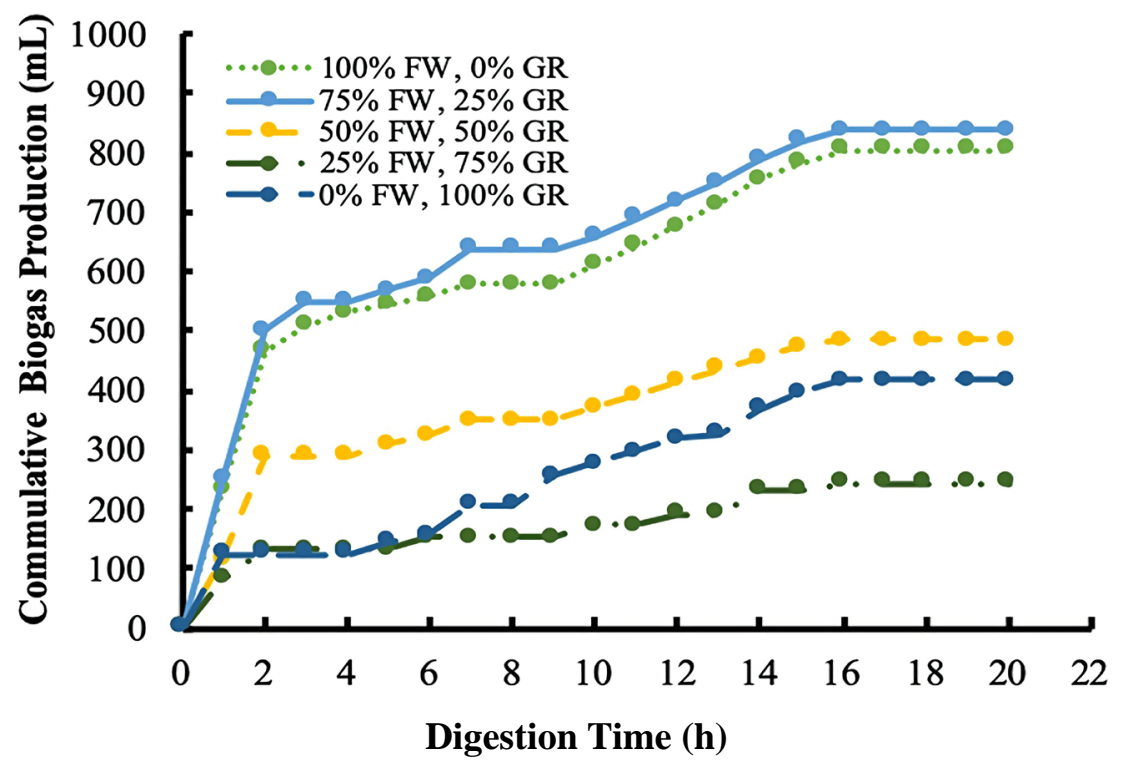

Figure 2. Commulative biogas production of co-digestion of food waste and grass in diffrent percentages. 
ratio, but mixture of different materials can alter the overall $\mathrm{C} / \mathrm{N}$ ratio of the total feedstock. The result shows that this sample contains the $\mathrm{C} / \mathrm{N}$ ratio which approaches the optimum $\mathrm{C} / \mathrm{N}$ ratio of 30:1. R4 produced the least of the biogas which is similar to the studies by Okonkwo et al. [33]. They reported that the sample containing $25 \%$ poultry dropping and $75 \%$ groundnut shell had the least desirable value of $\mathrm{C} / \mathrm{N}$ ratio. The bacteria responsible for the anaerobic process required both elements, as do all living organisms, but they consume carbon roughly 30 times faster than nitrogen. Assuming all other conditions are favourable for biogas production, a carbon-nitrogen ratio of about 30:1 is ideal for the raw material fed into a biogas plant. A higher ratio will leave carbon still available after the nitrogen has been consumed, starving some of the bacteria of this element. These will in turn die, returning nitrogen to the mixture, but slowing the process. Too much nitrogen will cause this to be left over at the end of digestion (which stops when the carbon has been consumed). The correct ratio of carbon to nitrogen will prevent the loss of methane content [33].

\section{Conclusion}

Biogas is produced by the anaerobic digestion of grass and food waste. Over a period of twenty (20) days, $840 \mathrm{~mL}$ of biogas was produced from a mixture of food waste and grass. A mixture of $25 \%$ grass and $75 \%$ food waste produced the largest volume of biogas. It is suggested that a ratio of $25 \%$ grass and $75 \%$ food waste should be used for co-digestion of food waste and grass. The digester after acidogenesis stage took only one day to begin biogas production and produced a higher volume of the total, hence it is suggested that the first two days should be the peak days for biogas collection. Further studies would be carried out in bigger volume reactors (5 L AND $10 \mathrm{~L}$ ) and also on a pilot scale.

\section{Conflicts of Interest}

The authors declare no conflicts of interest regarding the publication of this paper.

\section{References}

[1] Rodriguez, C., Alaswad, A., Benyounis, K.Y. and Olabi, A.G. (2017) Pretreatment Techniques Used in Biogas Production from Grass. Renewable and Sustainable Energy Reviews, 68, 1193-1204. https://doi.org/10.1016/j.rser.2016.02.022

[2] Prochnow, A., Heiermann, M., Plöchl, M., Linke, B., Idler. C. and Amon, T. (2009) Bio-Energy from Permanent Grass Land: A Review: 1. Biogas. Bio-Resource Technology, 100, 4931-4944. https://doi.org/10.1016/j.biortech.2009.05.070

[3] FAOSTAT (2014) Agri-Environmental Indicators. http://faostat3.fao.org/browse/E/EL/E

[4] Carlier, L., Rotar, I., Vlahova, M. and Vidican, R. (2009) Importance and Functions of Grass-Lands. Notulae Botanicae Horti Agrobotanici Cluj-Napoca, 37, 25-30.

[5] Olabi, A.G. (2009) The 3rd International Conference on Sustainable Energy and Environmental Protection SEEP-Guest Editor's Introduction. Energy, 35, 4508-4509. 
https://doi.org/10.1016/j.energy.2010.09.053

[6] Kaur, K., Phutela, U.G. and Goyal, M. (2016) Comparative Analysis of Fodder Beet and Napier Grass PBN233 as a Better Substrate for Biogas Production. Indian Journal of Science and Technology, 9, 1-4. https://doi.org/10.17485/ijst/2016/v9i3/56765

[7] University of Kentucky (2013) Switchgrass for Bioenergy.

[8] Rinehart, L. (2006) Switchgrass as a Bioenergy Crop. Bioresource Technology, 56, 83-93. https://doi.org/10.1016/0960-8524(95)00176-X

[9] Smyth, B.M., Murphy, J.D. and O’Brien, C.M. (2009) What Is the Energy Balance of Grass Biomethane in Ireland and Other Temperate Northern European Climates? Renewable and Sustainable Energy Reviews, 13, 2349-2360. https://doi.org/10.1016/j.rser.2009.04.003

[10] Uçkun Kiran, E. and Liu, Y. (2015) Bioethanol Production from Mixed Food Waste by an Effective Enzymatic Pretreatment. Fuel, 159, 463-469.

https://doi.org/10.1016/j.fuel.2015.06.101

[11] Zhang, R., El-Mashad, H.M., Hartman, K., Wang, F., Liu, G., Choate, C. and Gamble, P. (2006) Characterization of Food Waste as Feedstock for Anaerobic Digestion. Bioresource Technology, 98, 929-935. https://doi.org/10.1016/j.biortech.2006.02.039

[12] Mshandete, A., Kivaisi, A., Rubindamayugi, M. and Mattiasson, B. (2004) Anaerobic Batch Co-Digestion of Sisal Pulp and Fish Wastes. Bioresource Technology, 95, 19-24. https://doi.org/10.1016/j.biortech.2004.01.011

[13] Parawira, W., Murto, M., Zvauya, R. and Mattiasson, B. (2004) Anaerobic Batch Digestion of Solid Potato Waste alone and in Combination with Sugar Beet Leaves. Renewable Energy, 29, 1811-1823. https://doi.org/10.1016/j.renene.2004.02.005

[14] El-Mashad, H.M. and Zhang, R. (2010) Biogas Production from Co-Digestion of Dairy Manure and Food Waste. Bioresource Technology, 101, 4021-4028. https://doi.org/10.1016/j.biortech.2010.01.027

[15] Mata-Alvarez, J., Macé, S. and Llabrés, P. (2000) Anaerobic Digestion of Organic Solid Wastes: An Overview of Research Achievements and Perspectives. Bioresource Technology, 74, 3-16. https://doi.org/10.1016/S0960-8524(00)00023-7

[16] Callaghan, F.J., Wase, D.A.J., Thayanithy, K. and Forster, C.F. (2002) Continuous Co-Digestion of Cattle Slurry with Fruit and Vegetable Wastes and Chicken Manure. Biomass Bioenergy, 27, 71-77. https://doi.org/10.1016/S0961-9534(01)00057-5

[17] Misi, S.N. and Forster, C.F. (2001) Batch Co-Digestion of Multi-Component Agro-Wastes. Bioresource Technology, 80, 19-28. https://doi.org/10.1016/S0960-8524(01)00078-5

[18] Sun, Y. and Cheng, J. (2002) Hydrolysis of Lignocellulosic Materials for Ethanol Production: A Review. Bioresoure Technology, 83, 1-11. https://doi.org/10.1016/S0960-8524(01)00212-7

[19] Kratky, L. and Jirout, T. (2011) Biomass Size Reduction Machines for Enhancing Biogas Production. Chemical Engineering \& Technology, 34, 391-399. https://doi.org/10.1002/ceat.201000357

[20] Kobayashi, N., Guilin, P., Kobayashi, J., Hatano, S., Itaya, Y. and Mori, S. (2008) A New Pulverized Biomass Utilization Technology. Powder Technology, 80, 272-283. https://doi.org/10.1016/j.powtec.2007.02.041

[21] Cadoche, L. and López, G.D. (1989) Assessment of Size Reduction as a Preliminary 
Step in the Production of Ethanol from Lignocellulosic Wastes. Biological Wastes, 30, 153-157. https://doi.org/10.1016/0269-7483(89)90069-4

[22] Hideno, A., Inoue, H., Tsukahara, K., Fujimoto, S., Minowa, T. and Inoue, S. (2009) Wet Disk Milling Pretreatment without Sulfuric Acid for Enzymatic Hydrolysis of Rice Straw. Bioresource Technology, 100, 2706-2711. https://doi.org/10.1016/j.biortech.2008.12.057

[23] Igathinathane, C., Womac, A.R., Miu, P.I., Yu, M., Sokhansanj, S. and Narayan, S. (2006) Linear Knife Grid Application for Biomass Size Reduction. In: Proceedings of ASABE Annual Meeting, Portland, Paper No. 066170. https://doi.org/10.13031/2013.21524

[24] Bolzonella, D., Pavan, P., Battistoni, P. and Cecchi, F. (2005) Mesophilic Anaerobic Digestion of Waste Activated Sludge: Influence of the Solid Retention Time in the Wastewater Treatment Process. Process Biochemistry, 40, 1453-1460. https://doi.org/10.1016/j.procbio.2004.06.036

[25] Fabbri, A., Bonifazi, G. and Serranti, S. (2015) Micro-Scale Energy Valorization of Grape MARCS in Winery Production Plants. Waste Management, 36, 156-165. https://doi.org/10.1016/j.wasman.2014.11.022

[26] Datta, N.P., Khera, M.S. and Saini, T.R. (1962) A Rapid Colorimetric Procedure for the Determination of the Organic Carbon in Soils. Journal of the Indian Society of Soil Science, 10, 67-74.

[27] Jackson, M.L. (1967) Nitrogen Determination for Soils and Plant Tissue. Soil Chemical Analysis, 183-204.

[28] APHA-AWWA-WEF (2005) Standard Methods for the Examination of Water and Wastewater. APHA-AWWA-WEF, Washington DC, USA.

[29] Abu-Dahrieh, J.K., Orozco, A., Ahmad, M. and Rooney, D. (2011) The Potential for Biogas Production from Grass. In: Proceedings of the Jordan International Energy Conference, Amman.

[30] Feng, K., Li, H. and Zheng, C. (2018) Shifting Product Spectrum by pH Adjustment during Long-Term Continuous Anaerobic Fermentation of Food Waste. Bioresource Technology, 270, 180-188. https://doi.org/10.1016/j.biortech.2018.09.035

[31] Lee, H.V., Hamid, S.B.A. and Zain, S.K. (2014) Conversion of Lignocellulosic Biomass to Nanocellulose: Structure and Chemical Process. The Scientific World Journal, 2014, Article ID: 631013. https://doi.org/10.1155/2014/631013

[32] Patinvoh, R.J., Osadolor, O.A., Chandolias, K., Horváth, I.S. and Taherzadeh, M.J. (2017) Innovative Pre-Treatment Strategies for Biogas Production. Bioresource Technology, 224, 13-24. https://doi.org/10.1016/j.biortech.2016.11.083

[33] Okonkwo, U.C., Onokpite, E. and Onokwai, A.O. (2018) Comparative Study of the Optimal Ratio of Biogas Production from Various Organic Wastes and Weeds for Digester/Restarted Digester. Journal of King Saud University-Engineering Sciences, 30, 123-129. https://doi.org/10.1016/j.jksues.2016.02.002 